\title{
Nota
}

\section{New nesting locality of the Agami Heron, Agamia agami (Pelecaniformes: Ardeidae) in Ecuador}

\author{
Nueva localidad de anidación de la garza agami, Agamia \\ agami (Pelecaniformes: Ardeidae) en Ecuador
}

\author{
Flor M. Ortiz-Galarza y César Garzón-Santomaro
}

\begin{abstract}
The Agami heron, Agamia agami, is a rare species of the Neotropics, and even though its distribution is large, little is known about the sites where it congregates to nest. We report a new nesting site, which is the eighth reported site in the Neotropics, located in Tambococha, Yasuní National Park, Ecuador. We estimate that it is occupied by approximately 140 individuals, based on the 70 nests counted and considering the monogamous behavior of this species for at least one year. The discovery of this nesting colony is important to determine more precisely the distribution area of this species, and, in the future, monitor populations and develop studies of population genetics, migration, and behavioral movements as a basis to implement a conservation strategy for the Agami Heron in Ecuador.
\end{abstract}

Keywords. Amazonian alluvial plain. Bird nesting colonies. Neotropics.

\section{Resumen}

La garza Agamia agami es una especie rara que habita en el Neotrópico. Aunque su distribución es amplia, se sabe poco sobre los sitios donde se congrega para anidar. Reportamos un nuevo sitio de anidación, el octavo conocido en el Neotropico, ubicado en Tambococha, Parque Nacional Yasuní, Ecuador. Estimamos la presencia de aproximadamente 140 individuos, cifra que se basa en los 70 nidos contabilizados, considerando el comportamiento monógamo que presenta esta especie por lo menos en un año. El descubrimiento de esta colonia de anidación es importante para determinar con mayor precisión el área de distribución de esta especie y, en el futuro, realizar estudios genéticos poblacionales, movimientos migratorios, comportamentales y de monitoreo que sirvan de base para implementar una estrategia de conservación de la garza agami en Ecuador.

Palabras clave. Colonia de anidación de aves. Llanura aluvial Amazónica. Neotrópico. 


\section{Introduction}

The Agami Heron, Agamia agami, is a monotypic species and represents one of the survivors of the oldest heron lineage (Kushlan \& Hancock, 2005). The species is distributed in Mexico, and Central and South America (Kushlan \& Hafner, 2000), has solitary and diurnal behavior and is rarely observed throughout its distribution. This species occupies a variety of habitats that are of difficult access, such as areas of dense vegetation, ravines, and small streams, of which it prefers coastal mangroves in Central America and the Atlantic coast in South America (Stier \& Kushlan, 2015). Within the continent, it is distributed mainly in areas of swamp, igapós and freshwater wetlands in the Amazonian forests up to $300 \mathrm{~m}$ above sea level (Erize et al., 2006).

The Agami Heron is unique because, although it is a solitary forager, it nests in large colonies, (Kushlan \& Hancok, 2005). This heron only congregates during the nesting season, generally during the rainy season. It has been recorded that these herons begin to arrive at the nesting sites since March, and leave the nests in September (Abella-Gutiérrez \& Lopez-Conlon, 2008). The peaks of nesting and births are at the end of April and the end of May, respectively (Abella-Gutiérrez \& Lopez-Conlon, 2008); however, the start and end dates of the breeding season and its different stages can vary significantly from one colony to another at different latitudes, but it seems that this species prefers to nest during the rainy season. (AIDER, 2014; Stier \& Kushlan, 2015; www.tambopata-bahuaja.info/assets/ agami.pdf.). There is no confirmed information about the local and migratory movements of this species (Kushlan \& Hancok, 2005). Only one study, in Marais de Kaw-Roura Natural Reserve, in French Guiana, tracked eight individuals with telemetry, and found that after reproduction they moved between 280 and 1250 $\mathrm{km}$ in different directions along the Atlantic Coast of Venezuela, Guiana, Surinam and Brazil (Stier et al., 2017).
This species is extremely sensitive to habitat disturbance, and is classified as Vulnerable (BirdLife International, 2017; www.birdlife.org). The populations of Agamia agami have been threatened by different anthropic activities, including chemical contamination of water, intensive cultivation, excessive use of pesticides, crop harvest, floods, hunting, wood extraction and deforestation (Stier \& Kushlan, 2015). According to BirdLife International (2012), Agamia agami ranks second among the heron species considered conservation priorities in the Americas; between 19 and $26 \%$ of its habitat is estimated to be lost within the next three generations (BirdLife International, 2012; www.birdlife.org).

Until 2015, five countries with nesting localities were known: Costa Rica, Venezuela, Brazil, French Guiana, Trinidad and Tobago, (Abella-Gutierrez \& Lopez-Conlon, 2008; do Nascimento, 1990; Marin A, 1989; Ramo \& Busto, 1982; Reynoud \& Kushlan, 2004; Stier \& Kushlan, 2015; Stier et al, 2017). In 2017, a new nesting locality was reported in Mexico, the northernmost nesting locality known for this species (Correa et al., 2017). Another reported nesting area is in the Cocococha Lagoon in the Tambopata National Reserve in Peru, which was monitored from 2005 to 2014 (AIDER, 2014; www.tambopata-bahuaja. info/assets/agami.pdf.) but this data has not been published to date (Figure 1).

Currently, there is published information about the reproduction, nesting and breeding of the Agami Heron (Michener et al., 1964; Hancock \& Elliot, 1978; Abella-Gutiérrez \& López-Conlon, 2008; Kushlan \& Hines, 2016). However, no reproduction and nesting records have been reported in Ecuador. Here we report a new nesting colony of Agamia agami located in Tambococha, Yasuní National Park, Province of Francisco de Orellana, in Ecuador. 


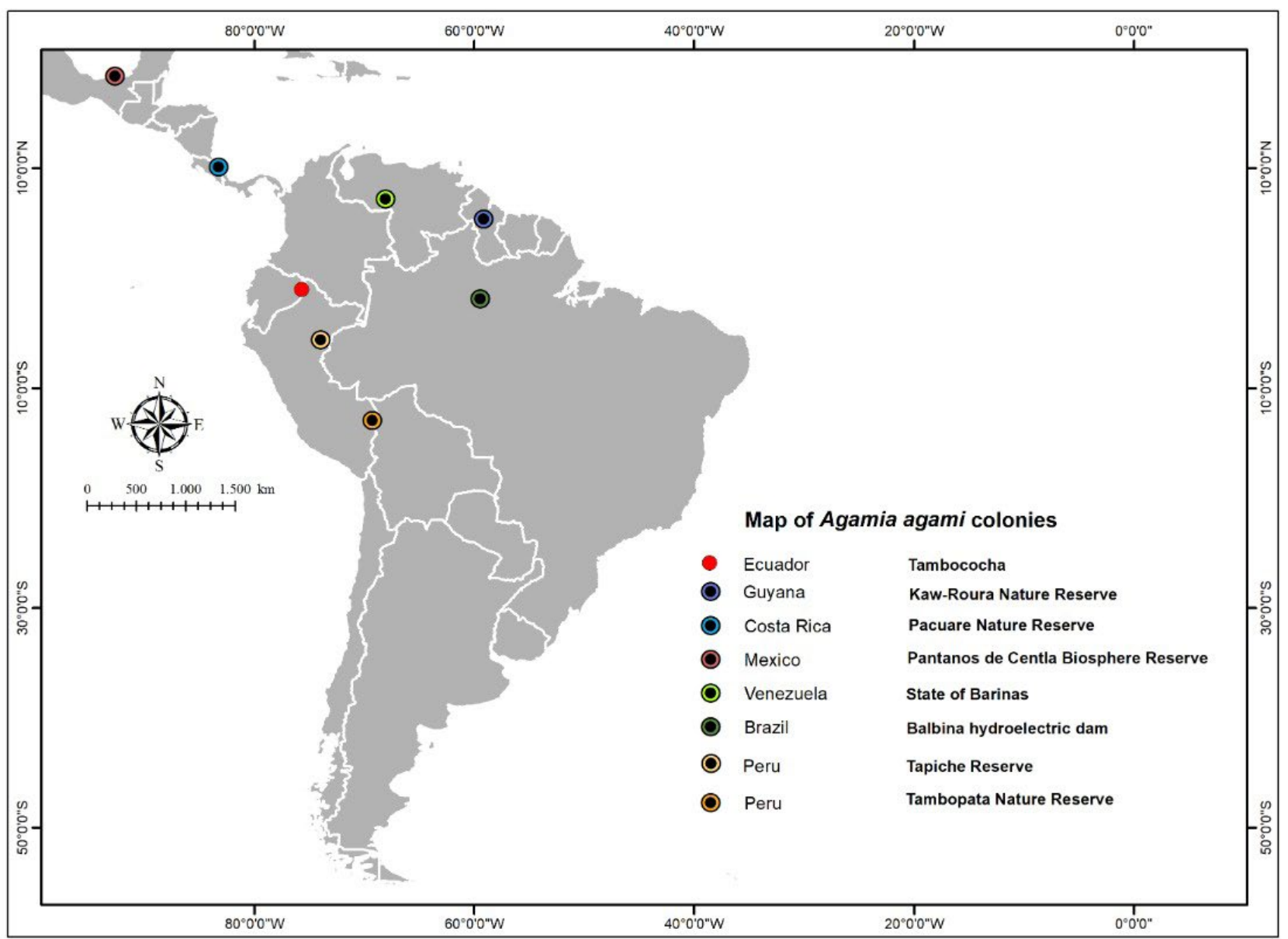

Figure 1. Map of recorded nesting colonies for the Agami Heron, Agamia agami, in South and Central America.

\section{Materials and methods}

The study area was located in Tambococha in the Yasuní National Park, six hours of navigation along the Tiputini River from Puerto Francisco de Orellana. The area corresponded to a flooded forest of the Amazonian alluvial plain (MAE, 2013), with vegetation dominated by the family Combretaceae, (Terminalia), Arecaceae, (Bactris) and Fabaceae and Urticaceae.

The nesting colony of $A$. agami was observed 70 m away from the boat, so the herons were not disturbed, as it is known that the species is very sensitive to human presence (Stier \& Kushlan, 2015). From the boat, three people counted the number of nests and individuals. In addition, pictures of the area were taken, in order to recount the nests. The observations were done by using Tasco Zip binoculars $10 \times 52 \mathrm{~mm}$ and a Cybershot camera with a $30 \mathrm{X}$ optical zoom.

\section{Results and discussion}

This colony was observed for the first time in 2016 by personnel of the Ministry of Environment of Ecuador (Figure 2). In March of 2017, we could confirm that the colony is still using the same location as a nesting site. 


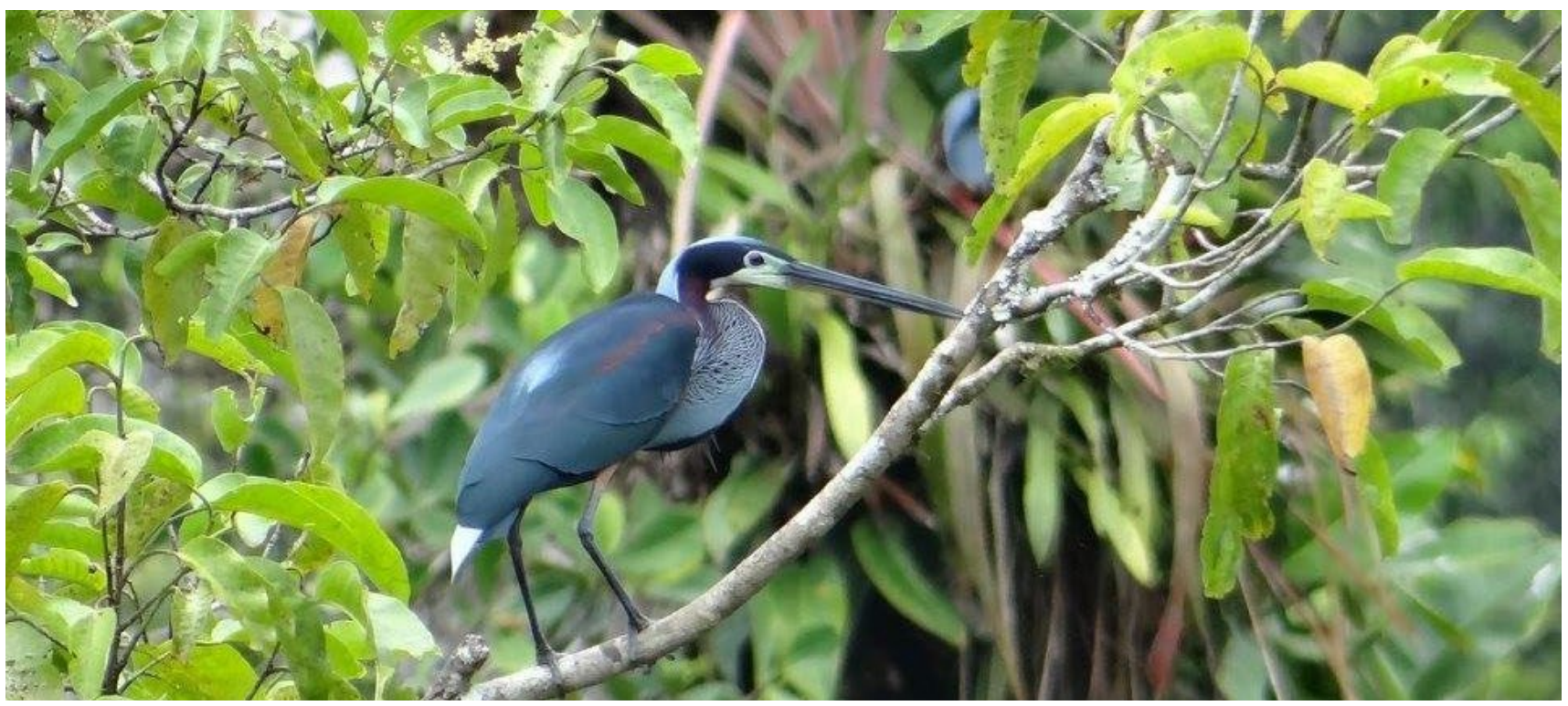

Figure 2. Agami Heron (Agamia agami), in Tambococha, Yasuní National Park, Ecuador. Photo: Flor M. Ortiz-Galarza.

The nesting colony of Agamia agami is found in Tambococha, Yasuní National Park (105"11"S, $\left.75^{\circ} 33^{\prime} 42^{\prime \prime} \mathrm{W}, 130 \mathrm{~m}\right)$. The nesting area is approximately 2 ha, and the nests are located together between 2 and 3 meters above water level (Figure 3).
Seventy nests were recorded, with at least one adult sitting on each, as if they were incubating, and some other adults were observed carrying thin branches to build the nest. Up to March 2017, no eggs were seen in the nests.

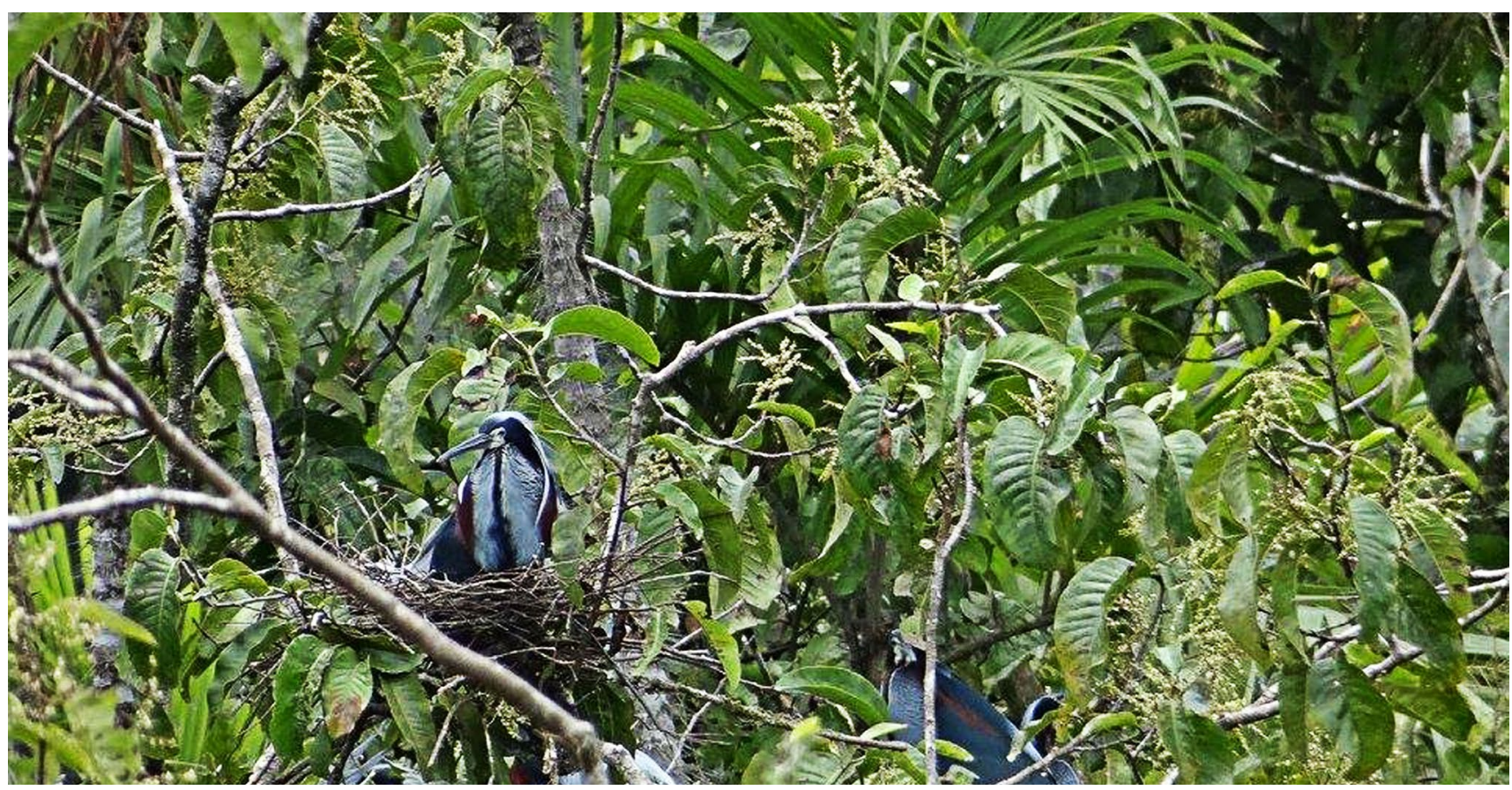

Figure 3. Nesting area of Agami Heron (Agamia agami) in the Amazon Rainforest, Tambococha, Yasuní National Park, Ecuador. Photo: Flor M. Ortiz-Galarza. 
Approximately 140 birds and an effective population of 70 individuals are estimated for the colony, figures that are based on the number of nests counted and if a monogamous behavior is considered for at least one year of reproduction and nesting for this species (Stier \& Kushlan, 2015). However, the population may be larger, since in this estimation it is assumed that all the observed individuals are breeding and mature.

Most of the reported nesting colonies are located in other parts of the species' range, in the lowland forests of Costa Rica, and in mangroves in Guyana, Mexico and Costa Rica. There is only one nesting colony reported for Central Amazonia, in the swamp forests of Brazil, and three reported colonies in Peru and Ecuador, in the western Amazonian plains (Abella-Gutierrez \& Lopez-Conlon, 2008; Correa et al., 2017; do Nascimento, 1990; Marin A, 1989; Ramo \& Busto, 1982; Stier \& Kushlan, 2015; AIDER, 2014; www.tambopata-bahuaja.info/assets/agami.pdf.).

The newly found colony of Agamia agami in Tambococha is smaller than the one registered in Mexico, with 170 nests (Correa, 2017), as well as the colony of Marais de Kaw-Roura Natural Reserve in French Guiana, with 1000 nests (Stier et al., 2017), considered the largest one in South America. However, the colony of Tambococha is similar to the one in Costa Rica, with 73 nests (Alvarado, 2006), larger than the one reported in Brazil, with 26 nests (Do Nascimento, 1990), and the one reported in Tambopata Natural Reserve, with 33 individuals recorded in the last monitoring year 2013/2014 (AIDER, 2014;www. tambopata-bahuaja.info/assets/agami.pdf.). At the latter site, more than 500 breeding individuals were recorded in 2005-2006, and it was considered the second largest colony in South America (AIDER, 2014; www.tambopata-bahuaja. info/assets/agami.pdf.).

Of the eight localities with nesting colonies of A. agami, three are not within protected areas: State of Balbina, Brazil (last sighting report was in 1988); Puerto Limón, Costa Rica (less than 20 reproductive pairs recorded in 1985); and in the State of Barinas, Venezuela (about 2000 pairs, recorded in 1980). The other five known colonies are within natural reserves (Costa Rica, French Guiana), areas of protection (Mexico), National Reserve (Peru) and National Park (Ecuador).
Although the Amazonian ecosystems have suffered great impacts due to human activities, and this has caused the detriment of some bird populations, the A. agami nesting colony is located within the Yasuní National Park in an area almost inaccessible to humans.

The discovery of this nesting colony contributes to a more precise knowledge of the distribution area of A. agami. Furthermore, the finding of this nesting site will be important for future studies about migratory movements of this species with other nearby colonies such as those of Peru and Brazil. In addition, it is a farther step to know its regional migratory movements and its relationship with other nearby colonies such as those of Peru and Brazil. According to Stier et al. (2017) the study in French Guiana suggests that a colony may possibly be composed of different populations that congregate to nest, and then are redistributed regionally. For this reason, it is crucial to establish annual monitoring of the Agami Heron in Tambococha, including a study of reproduction, demography, migration patterns and population genetics.

Finally, a conservation strategy in Tambococha must be developed not only in the nesting area, but also in the surrounding forest. In French Guiana it was determined that a nesting colony of $A$. agami should be supported by thousands or perhaps tens of thousands of hectares of natural habitat for foraging. This information suggests the importance of protecting not only the colony site, but also a representative amount of habitat (Stier et al., 2017). This assumption is supported by records of Kushlan \& Hines (2016), who found that nesting individuals have wide ranges of dispersion that exceed $200 \mathrm{~km}^{2}$ and adults feeding their young did not return daily.

\section{Acknowledgements}

We thank Efraín Freire, who helped us with the identification of plants, and Mónica Páez, for comments on the manuscript. We also thank Mateo Vega, who helped with the distribution map, and Gabriel Maldonado Casanova, who helped us find the nesting colony of Agamia agami. 


\section{References}

Abella-Gutiérrez, I. \& López-Conlon, M. (2008). Fenología reproductiva de una colonia de Garza Agami (Agamia agami, Aves: Ardeidae) en la Reserva Pacuare, Costa Rica. Brenesia, 69, 77-79.

Alvarado, G. (2006). Conservación de las aves acuáticas de Costa Rica. Brenesia, 66, 49-68.

Correa Sandoval, J., Escalona Segura, G. \& García Reynoza, X. (2017). Descubrimiento de un sitio de anidación de Garza monjita. CONABIO. Biodiversitas, 133, 1-5.

Do Nascimento, J. L. X. (1990). Reprodução de Agamia agami na usina hidreléctrica Balbina, Amazonas, Brasil. Ararajuba, 1, 79-83.

Erize, F., Rodríguez, J. R. \& Rumboll, M. (2006). Birds of South America, Non Passerines: Rheas to Woodpeckers. USA: Princeton University Press.

Hancock J. \& Elliot, H. (1978). The herons of the world. New York: Harper and Row.

Kushlan, J. A. \& Hafner, H. (2000). Conserving herons. New York: Academic Press.

Kushlan, J. A. \& Hancock, J. A. (2005). The Herons. Oxford, U.K.: Oxford University Press.
Kushlan, J. \& Hines, K. (2016). Behavior of the Agami Heron (Agamia agami). Waterbirds, 39(2), 187-192.

Marin, M. (1989) Notes on the breeding of Chestnut-bellied Herons (Agamia agami) in Costa Rica. Condor, 91(1), 215-217.

Michener, M. C., Weske, J. S. \& Clapp, R. B. (1964). A breeding colony of Agami Herons in Veracruz. Condor, 66, 77-78.

Ministerio del Ambiente de Ecuador, MAE. (2013). Sistema de Clasificación de los Ecosistemas de Ecuador Continental. Quito: Subsecretaría de Patrimonio Natural, Quito, 235 pp.

Ramo, C. \& Busto, B. (1982). Notes on the breeding of the Chestnut-bellied Heron (Agamia agami) in Venezuela. The Auk, 99(4), 784.

Reynaud, P. A. \& Kushlan, J. A. (2004). Nesting of the Agami Heron. Waterbirds, 27(3), 308-311.

Stier, A. \& Kushlan, J. (2015). Plan de conservación de la Garza agami (Agamia agami). Guayan Francesa: Asociación GEPOG.

Stier, A., Ricardou, A., Uriot, S., de Pracontal, N. \& Kushlan, J.A. (2017). Breeding season, home range and migration of the Agami Heron (Agamia agami). Waterbirds, 40(3), 289-296.

\section{Flor M. Ortiz-Galarza}

Universidad Tecnológica Indoamérica

Quito, Ecuador

ing.florortiz@gmail.com

https://orcid.org/0000-0002-2482-5272

\section{César Garzón-Santomaro}

Instituto Nacional de Biodiversidad

Quito, Ecuador

cesar.garzon@biodiversidad.gob.ec

https://orcid.org/0000-0001-6171-3686
New nesting locality of the Agami Heron, Agamia agami (Pelecaniformes: Ardeidae) in Ecuador

Citación del artículo: Ortiz-Galarza, F. M. \& GarzónSantomaro, C. (2019). New nesting locality of the Agami Heron, Agamia agami (Pelecaniformes: Ardeidae) in Ecuador. Biota Colombiana, 20(1), 126-131. DOI: 10.21068/c2019.v20n01a09.

Recibido: 19 de junio de 2018

Aceptado: 9 de abril de 2019 